\title{
Regulating PPP Projects in the Energy Sector: An Exploratory Survey of Skills Required
}

\author{
Abdullahi A. Umar ${ }^{a} *$, Noor Amil W. A. Zawawi ${ }^{b}$, Abdul Rashid Abdul Aziz ${ }^{c}$, Taleb M. Al-Rousan ${ }^{a}$ \\ ${ }^{a}$ Alhosn University, Old Airport Road, Delma Street 13, Al-Musalla, Abu Dhabi, U.A.E \\ ${ }^{b}$ Universiti Teknologi PETRONAS, Bandar Seri Iskandar, 31750 Tronoh Perak, Malaysia \\ ${ }^{c}$ Universiti Sains Malaysia, Pulau Pinang, 11800 Penang, Malaysia
}

\begin{abstract}
The involvement of the private sector in the provision of public services through concessions has been growing over the years and the energy sector has seen its own fair share of such concessions. Because these services have monopoly characteristics, regulatory institutions were set up to protect society from monopoly exploitation, inefficiencies and market failures. However, there has been a growing disenchantment with the state of service provision around the globe and consumers are blaming regulatory institutions' inability to protect them. The effectiveness of any regulatory institution is dependent on the expertise and competence of its staff. Therefore, this study seeks to determine the capacity requirement for effective regulatory governance and how best the present capacity gaps can be filled. This study reports the results of a survey of 101 energy industry stakeholders in public and private sectors across 35 countries. It was found that expertise in management, contract design, business analysis, project management, facilities management, risk management, ex-post negotiations, and sector-specific knowledge were crucial to the effective performance of regulatory institutions. Recruiting experts from the private sector was considered the most effective method of filling the capacity gaps in regulatory institutions.
\end{abstract}

Keywords: PFI/PPP; Infrastructure regulation; Skills

\section{Introduction}

Energy forms the back bone of modern economies because of its input status in almost every aspect of human activity. The economic impact of one hour without energy across the globe would lead to uncontrollable chaos globally. There has been an increase in energy demand resulting from rising incomes in emerging economies with China, India and the Middle East projected to account for $60 \%$ of this increase by 2035 (IEA, 2012 ). The link between economic growth and energy demand has been established (Abid \& Sebri, 2012) (Shaari, Hussain, \& Ismail, 2013) (Chen, Kuo, \& Chen, 2007). It has also been found that an extra productivity corresponding to \$US1120-\$1740 was

${ }^{*}$ Corresponding author

E-mail: a.umar@alhosnu.ae

(C) 2016 International Association for Sharing Knowledge and Sustainability

DOI: $10.5383 /$ ijtee. 11.01 .004 achieved for every 1 Mega Watt (MW) increase in electricity supply (Morimoto \& Hope, 2004).

In developing countries of Africa, energy has been touted as a key factor in the fight against poverty and elimination of inequalities (Hall \& Niekerk, 2013, p. 3). However, on a positive note, the sources of energy are also as diverse as its uses. Electricity can be generated from hydro-plants, fossil fuel powered plants, nuclear plants, Natural gas, coal and Solar Photovoltaic cells (PV). Furthermore, in response to climate change, newer sources referred to as 'renewables' such as geothermal, biomass, and wind have been developed in a bid to curtail the environmental impact of current sources of energy. Despite numerous sources of electricity available and the advent of 'renewable' sources, security of supply is still a big challenge for governments across the globe. The energy sector is so important that 
globally governments still subsidise its supply. The sector received government subsidies of about $\$ 523$ billion in 2011; this figure is 6 times more than subsidies to renewables (IEA, 2012). Governments around the globe have been facing increasing challenges of sustaining investments in electricity and catering to other societal needs.. However, in order to meet demand requirements, governments have looked to the private sector for assistance in the form of independent power producers (IPPs) under an arrangement known as private finance initiatives (PFI) or public-private partnerships (PPP). The PFI strategy involves the licensing of a private consortium to provide public services for a specified duration in return for a service charge. This strategy has been employed globally for the provision of water and sanitation services, roads, telecommunications, ports and airports and energy. Under this arrangement the government takes the position of a regulator either directly or through an agency or commission created specifically for the purpose. The agency is empowered to regulate the quality of service, tariff and other important aspects that may affect both users and government adversely, for example, environmental quality issues. However, with growing disenchantments with the quality of services and tariff hikes under private provision, it seems that regulators have not been well equipped to discharge their regulatory mandates. This may explain why it took the office of gas and electricity market (Ofgem) 5 years to discover that one of its private providers has been over charging consumers (Mason, 2012). Although it has been argued that there are three qualities (competence, independence \& legitimacy) that must be possessed by regulators to be efficient (Trémolet, Shukla, \& Venton, 2004, p. 9); practitioners and researchers have only focused on independence/autonomy. However, with increasing disenchantment with services and tariffs globally, it is becoming clearer that attention needs to also focus on bureaucratic quality (Serebrisky, Azumendi, \& Andres, 2011). Most works in the area of regulatory governance have seldom sought to highlight the types of skills that are required for efficient regulatory governance. Even where trainings were provided to regulators, they were too general to be useful, hence regulators across both developed and developing countries are faced with capacity shortfall. This has led to calls for outsourcing of regulatory functions (Trémolet, Shukla, \& Venton, 2004) \& (Trémolet, 2007). But outsourcing has grave consequences for the public sector and would compound legitimacy problems already being experienced due to private involvement in services provision. There has not been a concerted effort to determine the types of expertise that is required for efficient regulatory governance in the energy sector. Therefore, this study seeks to investigate and determine empirically, the major skills/competence requirement for regulatory governance in the energy sector and also how best to overcome staff capacity shortfall in the sector.

\section{Regulatory Challenge in the Energy Sector}

Over the last couple of decades, there has been an increasing tendency to grant concessions to private companies to build, finance, maintain and supply energy. The practice of private provision of utilities services is not limited to industrialised countries, emerging economies and developing countries have also adopted the concessions model for most network-bound utility services including energy. . The practice of engaging private companies to provide energy is borne out of the belief that the private sector has better management expertise and was not constrained by bureaucratic redtape in decision making. Therefore they are better poised to provide services more efficiently. Table 1 below shows a profile of energy projects involving private investments according to regions.

Table 1: New Energy Projects with Private Participation

\begin{tabular}{|c|c|c|c|c|c|c|}
\hline Region & $\begin{array}{l}\text { No of } \\
\text { Cou } \\
\text { ntrie } \\
\text { s }\end{array}$ & $\begin{array}{l}\begin{array}{l}\text { No } \\
\text { of } \\
\text { Pro }\end{array} \\
\text { ject } \\
\text { s }\end{array}$ & $\begin{array}{l}\text { Value } \\
(\$ \\
\text { Billion })\end{array}$ & Output & $\begin{array}{l}\% \\
\text { foreign } \\
\text { equity }\end{array}$ & $\begin{array}{l}\text { Dominant } \\
\text { input }\end{array}$ \\
\hline Africa & 6 & 9 & $\$ 1.496$ & $\begin{array}{l}752 \mathrm{M} \\
\mathrm{W}\end{array}$ & $89 \%$ & Diesel \\
\hline $\begin{array}{l}\text { East } \\
\text { Asia \& } \\
\text { Pacific }\end{array}$ & 7 & 56 & $\$ 6.1$ & $\begin{array}{l}4.2 \mathrm{G} \\
\mathrm{W}\end{array}$ & $9 \%$ & $\begin{array}{l}\text { Natural } \\
\text { gas }\end{array}$ \\
\hline $\begin{array}{l}\text { Europe } \\
\& \\
\text { Central } \\
\text { Asia }\end{array}$ & 7 & 47 & $\begin{array}{l}\$ 10.1 \mathrm{Bi} \\
\text { llion }\end{array}$ & $\begin{array}{l}5.4 \mathrm{G} \\
\mathrm{W}\end{array}$ & $40 \%$ & $\begin{array}{l}\text { Natural } \\
\text { Gas }\end{array}$ \\
\hline $\begin{array}{l}\text { Lat. Am } \\
\& \\
\text { Caribbe } \\
\text { an }\end{array}$ & 11 & 68 & $\begin{array}{l}\$ 18.9 \mathrm{Bi} \\
\text { llion }\end{array}$ & $9 \mathrm{GW}$ & $59 \%$ & $\begin{array}{l}\text { Natural } \\
\text { Gas }\end{array}$ \\
\hline $\begin{array}{l}\text { South } \\
\text { Asia }\end{array}$ & 4 & 62 & 19.2 & $\begin{array}{l}15.2 \mathrm{G} \\
\mathrm{W}\end{array}$ & $20 \%$ & Coal \\
\hline MENA & - & - & - & - & - & - \\
\hline $\begin{array}{l}\text { IDA } \\
\text { Countri }\end{array}$ & 22 & 22 & $\begin{array}{l}\text { 1.7Billi } \\
\text { on }\end{array}$ & $\begin{array}{l}1.7 \mathrm{G} \\
\mathrm{W}\end{array}$ & & \\
\hline
\end{tabular}

Source: Compiled by authors from (PPIAF, 2012)

Although private investment in energy decreased by $11 \%$ compared to the year 2010 , there was still a substantial level of private involvement in energy generation and supply as is shown in table 1 above. And according to PPIAF (2012, p.1) in 2011, 242 new energy projects with private participation reached financial close in 35 lower-and-upper-middle income countries resulting in total investment commitments of about US\$70.1 billion (US\$78.5 billion for 2010).

Recognizing the problem of market failures and monopoly inefficiencies under private provision of essential services, regulatory agencies were created to regulate the activities of the private companies generating and distributing energy. Over 100 countries have established energy/electricity regulators since 1995 
across the globe (Stern, 2006 ). And these regulators had functions ranging from policy advice to government on energy related matters to direct enforcement of concession contracts. According to (Tenenbaum, 1996) \& (Berg, 2001), a review of experiences around the globe on the functions of energy regulators indicates that their key responsibilities include the following

1. Issuing licenses related to regulatory functions,

2. Setting performance standards,

3. Monitoring the performance of regulated firms,

4. Establishing/Approving the level and structure of tariffs,

5. Establishing a Uniform Accounting System,

6. Arbitrating disputes among stakeholders,

7. Performing (often via independent consultancy) management audits on regulated firms,

8. Developing human resources for the Independent Regulatory Commissions (IRC)

9. Reporting sector and IRC activities to the appropriate government authority

The regulators were also mandated to ensure the viability of private investments while protecting consumers from monopoly exploitation (Jacobs, 2004).

In a recent study using a sample of 301 PFIs and 926 State Owned Enterprise (SOEs) in both electricity and water sectors across 71 developing and transition countries, it was found that the involvement of the private sector did not lead to any significant investment gains even though it increased efficiency (Gassner, Popov, \& Pushak, 2008 , p. 4). The problem has become acute in some countries resulting in violent protests against private involvement in the energy sector. Consumers around the world are increasingly sceptical of private participation in network-utilities and even more sceptical of the regulators who were meant to protect their interests. Consumer despair stems from the fact that they cannot sanction the private provider for poor performance due to the concept of 'privity of contract'. A recent survey of Latin American consumers revealed that $65 \%$ of the population surveyed indicated that they would only support private participation in utilities if it were accompanied by credible and effective regulation (Brown, Stern, Tenenbaum, \& Gencer, 2006, p. 13).

Highly qualified and well paid staff are less likely to give in to political pressures or succumb to bribes or other inducements from the industry

(Kerf, Gray, Irwin, \& Levesque, 1998, p. 132). But the quality of regulatory staff has always been a problem because according to Hewitt (2004) the range of skills required for utilities regulation is special and relatively scarce. This scarcity is a major concern for regulatory governance in developing countries (Kessides, 2004, p. 88). The situation is not different in the UK either, where Stern (2000, p. 9) affirms that the difficulties of recruiting and retaining staff with the skills and ability to carry out such regulatory tasks are by no means trivial. And Eberhard (2006, p.7) asserts that regulatory substance, which are the outcome of regulatory decisions, can be compromised by inadequately trained and experienced regulators.

However, in response to capacity issues among regulators, it has been suggested that regulatory functions be outsourced (Trémolet, Shukla, \& Venton, 2004). But Trémolet (2007, p.11) cautioned that outsourcing regulatory functions comes with high transaction costs, it is difficult to manage, it is politically sensitive, it has continuity problems, reliance on external advise remains harmful in the long term, there is conflict of interests and is prone to conflicts in the long run. Therefore, there have been suggestions of recruiting experts from the private sector but this has been difficult because such experts would have to be remunerated according to existing civil service remuneration rules. Such experts would rather remian in the private sector where the remuneration package is better. But UNECE (2008, p.23) has argued that although these regulatory governance skills are scarce within government ministries, they however concede that the skills are acquirable. For example a World Bank sponsored survey of 37 regulators across the globe revealed that $30 \%$ said the training they have had was insufficient while $61 \%$ claimed the training support for capacity building was deficient. The respondents were further asked how deficient they thought the trainings were. And 38\% claimed it lacked continuity, 33\% claimed the training were insufficiently targeted while a further $25 \%$ claimed the training were too general (Trémolet \& Shah, 2005, p. 5). Another survey in the UK reports that only $48 \%$ of respondent admitted that what they were taught was useful to them in their tasks in the last 12 months (NAO, 2011). These findings seem to suggest that these trainings were poorly planned without first identifying the types of skills required by regulators before embarking on such trainings. Furthermore, regulation involves a diverse array of tasks executed by different professionals; hence it is equally important to understand these skill requirements from individual professional perspectives. While the objectives of regulation may be the same across regions and countries (ICAS, 2010, p. 28), slight differences may exist due to differences in prioritising these objectives.

According to Kessides (2004), Regulatory institutions were dominated by engineers because it was earlier believed that regulation was a purely technical matter. The involvement of private financiers which led to the introduction of economic regulation into utilities regulation has changed the required skill mix for regulatory institutions. Professional with knowledge in accounting, financial and economic analysis are now highly valuable resources required by regulators (Kessides, 2004, p. 88). Other types of expertise needed now include skills in economics, law, finance, negotiations, (Kerf, Gray, Irwin, \& Levesque, 1998), (United Nations, 2005); Furthermore, skills in negotiation analysis and media relations management, policy, process understanding and client understanding (RICS Project Management Forum, 2003); technical skills, and project monitoring (UNECE, 2008, p. 28) have also been argued as relevant. Also business, contracting, and auditing skills seem to also play a major role in effective regulatory governance (United Nations, 2005).

One major problem that has bedeviled most regulators is the mandate that requires them to both ensure profitability of the private partners and protect consumers at the same time (Jacobs, 2004), a mandate which has been argued not to be 'politically feasible' in today's business environment (Kessides, 2004, p. 65). Therefore, regulators have to make trade-offs between the desires of the investors and consumers through proper and skillful stakeholder management (ElGohary, Osman, \& El-Diraby, 2006) and (Li, Ng, \& Skitmore, 2012). It is almost impossible to derive a win-win decision under utilities regulation (Correa, Pereira, Mueller, \& Melo, 2006 , p. 6), hence regulators have to be knowledgeable, skillful and use the media strategically to create an atmosphere 
of trust and legitimacy. As Berg (2001) puts it, "best practice regulatory institutions need to take a more active role in educating the public and in communicating sector developments to all stakeholders; it is said that 'the fewer the facts, the stronger the opinion'. One way to reduce the divisive role of rhetoric is to introduce information about the costs and benefits of different policy options. If the regulatory process is transparent, stakeholders (including political leaders) will better understand regulatory decisions" (Berg, 2001).

. In the short term, training is a high priority in areas such as price regulation, concepts of utility regulation, economic and financial techniques, and design and management of regulatory institutions. These are the major areas being currently outsourced by some regulators in countries where outsourcing regulatory functions is permitted (Trémolet, 2007, p. 4). But UNECE (2008, p.23) argues that since these skills are scarce within government ministries, it is therefore best to bring experts from the private sector. This would remain a big debate in the area of regulatory capacity in many countries.

\section{Methodology}

Following evidence from literature, and thematic analysis (Boyatzis, 1998) \& (Braun \& Clarke, 2006) of the functions, roles and mandates of all the energy/electricity regulatory agencies globally, a list of 31 skills required by regulatory agencies were drawn up. An online questionnaire was designed to seek the opinions of staff of energy regulatory agencies across the globe. The online questionnaire was chosen because of its advantages of time, cost and access to remote populations (Evans \& Mathur, 2005).

The survey instrument was designed to ask "how important the respondents felt a particular skill was to staff of energy regulatory institutions' on a 5 point Likert scale. The question was framed this way in order to eliminate the bias ever present in sensitive self-assessment surveys (Trémolet \& Shah, 2005, p. 4). With the value 5 signifying that the respondent 'strongly agrees' that the skills was important while the value 1 signifying that the respondent 'Strongly Disagrees' that the skill in question was of any significance to energy regulatory staff. The resulting data was analysed using IBM's SPSS version 21 statistical package to draw inferences. Inferences and discussions enable the researcher to present the issues arising out of the research from two perspectives separated in time - that prior to the execution of the empirical work and that following its execution and production of results. Comparison of the two perspectives is important to demonstrate how knowledge has changed due to the study - to reinforce or to question the previously 'perceived wisdom' (Fellows \& Liu, 2008, p. 272).

\section{Results and Discussions}

101 respondents completed the online questionnaire and this figure is higher than other published works like (Isik, Arditi, Dikmen, \& Birgonul, 2009) with 73 respondents and (Belassi $\&$ Tukel, 1996) with 91 respondents.

The respondents also cut across all the regions of the world with Africa having 12 respondents, Asia 24, Europe 34, Middle East 8, North America 8, Latin America 10 and Oceania (Australia \& New Zealand) 5. In terms of qualifications, 19 respondents had Doctorate degrees, 54 had either an M.Sc. or MBA, 19 had a B.Sc. degree, 6 had a Diploma while 'other' qualifications had 3 respondents. Furthermore, respondents with over 5 years of industry experience constituted about $70 \%$ of the total respondents. From the respondents' profile, it can be seen that they are relatively qualified to give valid opinions on the subject matter. The reliability test conducted returned a Cronbach's alpha coefficient of $\alpha=.931$, indicating a very reliability score. The normality test returned a non-significant value for both Kolmogorov-Smirnov $(s i g=.200)$ and Shapiro-Wilk ( $s i g=$ .151) tests indicating that the distribution is normal. Therefore, the data would be analysed using parametric procedures. Since most of the categorical variables contain more than two groups, the main test available for use is one-way betweengroups analysis of variance (ANOVA) (Salkind, 2004, p. 196) and (Pallant, 2007, p. 242).

The comparison of the means of the distribution according to region $(\operatorname{sig}=.617)$ and years of industry experience $(\operatorname{sig}=.937)$ did not reveal any statistically significant difference in ranking. The result, while consistent with ICAS (2010, p.28), indicates that capacity requirements for regulatory governance in the energy sector are the same across regions and over time. This result is very important as it reinforces the position of Trémolet, et al., (2004) \& Trémolet (2007) on outsourcing of regulatory functions across regions. A further comparison across disciplines also reveals statistically significant (sig=.001) differences in ranking. The post Hoc (Duncan's) test reveals that the difference was between Account/finance professionals and all the other professions (lawyers, mechanical/electrical engineers, economists, and Public policy experts) except Civil/Construction professionals. Simply put, account and finance professionals are responsible for the major variation across disciplines having differed with four other disciplines within the group. The final comparison was based on the academic qualifications of respondents, the result was significant (sig=.001). The post Hoc (Duncan's) test revealed that the differences did not exist between holders of a B.Sc degree and 'other' qualifications. Also there was no statistical difference between respondents with $\mathrm{PhDs}$, M.Sc/MBA and Diplomas, but differences existed between group 1 (B.Sc \& 'Other') and group 2 ( $\mathrm{PhD}$, M.Sc/MBA and Diploma). The reason for this difference could not be isolated because the pattern of the groupings did not follow any known conventional pattern. However, despite the perceived differences, one interesting finding is the relatively high average mean of the respondents (mean=3.89). This indicates that the respondents were overall in agreement that the lists of skills presented to them were important in the regulatory process and hence need to be acquired by staff of energy regulatory institutions.

The mean scores of the variables as ranked by the respondents is shown on table 2 below and as expected 'risk identification and management skills' was ranked the most important overall. The efficient identification and management of risks has become the single most differentiating factor between successful and unsuccessful organisations. Sector-specific skills and technical skills came in $2^{\text {nd }}$ and $3^{\text {rd }}$ place respectively. Regulating a service provider requires the regulators to be knowledgeable in the intricacies involved in producing $1 \mathrm{MW}$ of electricity, this knowledge would assist in setting standards, setting and adjusting tariffs and designing licenses in this era of self-regulation through 'regulation by contracts' (Bakovic, Tenenbaum, \& Woolf, 2003). Output specification skills was ranked in $4^{\text {th }}$ place just behind sectorspecific skills, coincidentally these skills are interrelated in 
practice because without adequate technical and sector specific skills, writing and specifying the expected output level from any of the various sources of energy and their attendant plant and machinery capacity becomes guess work.

One of the greatest surprises of the ranking comes from the $28^{\text {th }}$ skill (Accounting \& Auditing skill), the entire sample of respondents contain 34 accounting and finance professionals and they happen to be the single most dominant group higher than all the engineers in the sample combined ( Civil/mechanical/electrical engineers $=33$ respondents). Considering the role that this group played in the Enron scandal and the impact of their activities in other spheres like financial regulation, it was expected that this skill would rank higher than where it is (28 $8^{\text {th }}$ place). What is even more intriguing is the fact that the respondents are a global collection of professionals who understand the impact of regulatory accounting and auditing on regulatory outcomes. Regulatory accounting and auditing is one of the major tasks being outsourced by regulatory agencies as found by Tremolet (2007) in her global survey of regulatory institutions.

\section{Table 2: Skills Ranked by their Mean Scores}

\section{Skills}

\begin{tabular}{|c|c|c|}
\hline & Skills & Mean Score \\
\hline 1 & Risk ID \& management & 4.54 \\
\hline 2 & Sector-specific Skills & 4.22 \\
\hline 3 & Technical skills & 4.21 \\
\hline 4 & Output specification skills & 4.11 \\
\hline 5 & Tariff Design Skills & 4.04 \\
\hline 6 & Economics Skills & 4.04 \\
\hline 7 & Performance management & 4.01 \\
\hline 8 & Stakeholder management skills & 4.00 \\
\hline 9 & Strategic Management skills & 3.98 \\
\hline 10 & Legal Skills & 3.96 \\
\hline 11 & Lifecycle Skills & 3.95 \\
\hline 12 & Communication strategy & 3.94 \\
\hline 13 & Project Management Skills & 3.94 \\
\hline 14 & Political Skills & 3.93 \\
\hline 15 & Contract Design Skills & 3.92 \\
\hline 16 & Management Skills & 3.92 \\
\hline 17 & Business analysis Skills & 3.91 \\
\hline 18 & Negotiation Skills & 3.88 \\
\hline 19 & Procurement skills & 3.84 \\
\hline 20 & Engineering Skills & 3.77 \\
\hline 21 & Financial Engineering \& Modeling & 3.76 \\
\hline & Data Collection \& Management & \\
\hline 22 & Skills & 3.75 \\
\hline 23 & Ex-post Negotiation skills & 3.74 \\
\hline 24 & Forecasting skills & 3.72 \\
\hline 25 & Sustainability/Environmental skills & 3.69 \\
\hline 26 & Negotiation analysis skills & 3.68 \\
\hline 27 & Media Relation skills & 3.60 \\
\hline 28 & Auditing \& Accounting Skills & 3.52 \\
\hline & Human capital/Org Assessment & \\
\hline 29 & Skills & 3.47 \\
\hline 30 & Health, Safety \& Environment Skills & 3.47 \\
\hline 31 & Facilities Management skills & 3.33 \\
\hline
\end{tabular}

this is that, practitioners still consider economic factors above sustainability/environmental concerns and this is consistent with what has been expressed by Johnson (2013).

Finally, the factor analysis conducted reveals that the entire 31 skills could be grouped under 8 extracted components or factors. Therefore, the major skills based on factor clustering are:
1) Project management
2) Business analysis,
3) Management,
4) Sector specific knowledge,
5) Facilities management,
6) Risk management,
7) Contract design
8) Ex-post negotiations.

The second objective of this study was to ascertain the most effective way of closing the capacity gap of regulatory agency staff. Although the number of respondents was 101, but due to the usual problem of missing data often associated with statistical packages (Khadaroo \& Abdullah, 2007), only 81 were accounted for. From the valid responses, 25 respondents supported training and seminars, 17 opted for coaching and mentoring by experienced staff while 39 supported direct recruitment of experts from the private sector. The result is not different from what other researchers have advocated in the past. The only challenge in adopting this process would be whether the government would grant regulatory agencies a special status to determine their own salary scales different from the normal civil service pay scales and the consequences on the morale of other public sector staff if this is permitted.

\section{Conclusions}

Private involvement in Infrastructure services has developed from merely being a major policy instrument of multi-lateral financial institutions (World Bank, IMF) and Donor Agencies (USAid, DfID) to a 'global movement' moving with a force that seem to almost rival those of environmental groups. However, in recent years, owing to the effect on society and the poor in particular, the momentum has slowed. Naturally, businesses are averse to their behaviour being regulated and would naturally seek ways to overcome whatever constraints they face from regulatory activities. Therefore, regulatory staff ought to be forward thinking and also possess very important regulatory skills to effectively guide the behaviour of their 'balance-sheet focused' private partners. To do this effectively requires their being a step ahead of their private partners in terms of skills and expertise in a number of areas which include business analysis, management, project management, facilities management, risk management, ex-post negotiations, contract design and sector specific knowledge. Furthermore, although recruiting additional capacity from the private sector was suggested as the most efficient way to fill the capacity gaps in regulatory agencies, remuneration differentials may constrain this from being effective. Therefore, concerted efforts should be made to develop the skills of existing staff through coaching by older more experienced staff where recruitment from the private sector becomes impractical due to budgetary constraints.
Another surprising ranking is the place of sustainability/environmental skills $\left(25^{\text {th }}\right.$ place $)$ considering the present place of climate change discourse in the global arena. The need for skills in sustainability and environmental protection is being ranked so poorly. A simple conclusion from 


\section{References}

[1] Abid, M., \& Sebri, M. (2012). Energy ConsumptionEconomic Growth Nexus: Does the Level of Aggregation Matter? International Journal of Energy Economics and Policy, 2(2), 55-62.

[2] Bakovic, T., Tenenbaum, B., \& Woolf, F. (2003). Regulation by Contract:A New Way to Privatize Electricity Distribution? Energy and $M$ ining Sector Board Discussion Paper, No 7. Washington D.C: The World Bank Group and Energy and M ining Sector Board.

[3] Belassi, W., \& Tukel, O. I. (1996). A New framework for determining critical sucess/failure factors in Projects. International Journal of Project Management, 14 (3), 141151.

[4] Berg, S. V. (2001). Infrastructure Regulation: Risk, Return, and Performance . Global Utilities, 1, 3-10 .

[5] Boyatzis, R. (1998). Transforming Qualitative Information: Thematic Analysis and Code Development. Thousand Oaks, CA: Sage.

[6] Braun, V., \& Clarke, V. (2006). Using Thematic Analysis in Psychology. Qualitative Research in Psychology,3 (2), 77 101

[7] Brown, A. C., Stern, J., Tenenbaum, B., \& Gencer, D. (2006). Handbook for Evaluating Infrastructure Regulatory Systems. Washington DC: The World Bank

[8] Chen, S.-T., Kuo, H.-I., \& Chen, C.-C. (2007). The relationship between GDP and electricity consumption in 10 Asian countries . Energy Policy, 35, 2611-2621.

[9] Correa, P., Pereira, C., Mueller, B., \& Melo, M. (2006 ). Regulatory Governance in Infrastructure Industries: Assessment and Measurement of Brazilian Regulators. Washington D.C: World Bank

[10] El-Gohary, N. M., Osman, H., \& El-Diraby, T. (2006). Stakeholder Management for Public Private Partnerships. International Journal of Project Management, 24, 595-604.

[11] Evans, J. R., \& Mathur, A. (2005). The value of online surveys . Internet Research, 15(2), 195-219.

[12] Fellows, R., \& Liu, A. (2008). Research Methods for Construction. U.K: Blackwell Publishing.

[13] Gassner, K., Popov, A., \& Pushak, N. (2008 ). Does Private Sector Participation Improve Performance in Electricity and Water Distribution? . Washington D.C: The World Bank.

[14] Hall, D., \& Niekerk, S. V. (2013). Overview of energy in Africa . UK: Public Services International Research Unit (PSIRU) .

[15] ICAS. (2010). Regulatory Governance in Developing Countries. Washington D.C: International Finance Corporation (IFC)/Investment Climate Advisory Services (ICAS).

[16] IEA. (2012 ). World Energy Outlook 2012 . France: OECD/ International Energy Agency .

[17] IEA. (2012). World Energy Outlook 2012: Executive Summary. France: OECD/ International Energy Agency.

[18] Isik, Z., Arditi, D., Dikmen, I., \& Birgonul, T. M. (2009). Impact of Corporate Strenght/Weaknesses on Project Management Competencies. International Journal of Project Management, 27 (6), 629-637.

[19] Jacobs, S. (2004). Governance of Asian Utilities: New Regulators Struggle in Difficult Environments . The Governance Brief, issue 10, 1-4.

[20] Kerf, M., Gray, D. R., Irwin, T., \& Levesque, C. (1998). Concessions for Infrastructure: A guide to their Design and Award. Washington D.C: The World Bank.

[21] Kessides, I. N. (2004). Reforming Infrastructure Privatization, Regulation, and Competition. Washington D.C: World Bank/Oxford University Press.
[22] Khadaroo, I., \& Abdullah, A. (2007). Private Finance Initiative (Public Private Partnership) Implementation Process and Perception of Value for Money. International Journal of Economics and Management, 1(3), 407-435.

[23] Li, T. H., Ng, S. T., \& Skitmore, M. (2012). Conflict or consensus: An investigation of stakeholder concerns during the participation process of major infrastructure and construction projects in Hong Kong. Habitat International, $36,333-342$

[24] Mason, R. (2012, 08 21). Energy companies 'overcharge customers by $£ 600 m$. Retrieved 07 20, 2013, from The Telegraph: http://www.telegraph.co.uk/earth/energy/9490712/Energycompanies-overcharge-customers-by-600m.html

[25] Morimoto, R., \& Hope, C. (2004). The Impact of Electricity Supply on Economic Growth in Sri Lanka . Energy Economics, 26(1), 77-85.

[26] NAO. (2011). Identifying and meeting central Government's skills requirements. UK: National Audit Office.

[27] Pallant, J. (2007). SPSS Survival Manual, 3rd Edition. England: McGraw-Hill.

[28] PPIAF. (2012). Private Participation in Infrastructure Database (2011 Energy Update: PPI Data Update Note 74). Washington D.C.: Public-Private Participation in Infrastructure Facility/World Bank

[29] RICS Project Management Forum. (2003). PFI and the Skills of a Manager. UK: RICS .

[30] Salkind, N. J. (2004). Statistics for People who (think they) Hate Statistics, 2nd Edition. United States of America: Sage Publications Inc.

[31] Serebrisky, T., Azumendi, S. L., \& Andres, L. A. (2011). Institutional Design and Governance of Airport Regulators: The Case of Latin America. Journal of Air Transport Management, 17, 207-210.

[32] Shaari, M. S., Hussain, N. E., \& Ismail, M. S. (2013). Relationship between Energy Consumption and Economic Growth: Empirical Evidence for Malaysia . Business Systems Review, 2 (1), 17-28.

[33] Stern, J. (2006 ). Evaluating Infrastructure Regulators Developing UK and International Practice. UK: Centre for the study of Regulated Industries (CRI).

[34] Tenenbaum, B. (1996). Regulation: What the Prime Minister Needs to Know. The Electricity Journal, 28-36.

[35] Trémolet, S. (2007). Outsourcing Regulation: When Does It Make Sense and How Do We Best Manage It? Working Paper No. 5. Washington D.C.: Public-Private Infrastructure Advisory Facility (PPIAF).

[36] Trémolet, S., \& Shah, N. (2005). «WANTED !Good Regulators for Good Regulation » An Evaluation of Human and Financial Resource Constraints for Utility Regulation -A Report by Environmental Resource Management (ERM) and Tremolet Consulting for the World Bank. London: World Bank.

[37] Trémolet, S., Shukla, P., \& Venton, C. (2004). Contracting Out Utility Regulatory Functions: Report by Environmental Resources Management for the World Bank. Washington D.C.: World Bank.

[38] UNECE. (2008). Guidebook on Promoting Good Governance in Public-Private Partnerships. New York and Geneva: United Nations.

[39] United Nations. (2005). Governance in Public Private Partnerships for Infrastructure Development. London: Economic Commission for Europe. 